Artikel Penelitian

\title{
PERUBAHAN PERILAKU PELAYANAN ANESTESI DAN BEDAH DI RUMAH SAKIT PADA ERA NEW NORMAL DI KOTA MAKASSAR
}

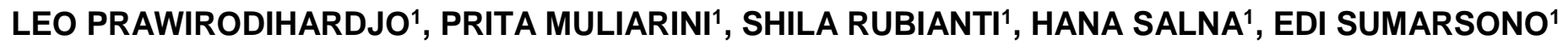 \\ ${ }^{1}$ Himpunan Obstetri dan Ginekologi Sosial (HOGSI)
}

Email korespondensi: leo.spog.k@gmail.com

Dikirimkan 15 April 2021, Diterima 19 Mei 2021

\begin{abstract}
Abstrak
Latar Belakang: Pelayanan kesehatan moderen sedang dihadapkan pada situasi yang mencekam, yaitu dengan pandemi severe acute respiratory syndrome corona virus 2 (SARS-CoV-2). Pembedahan sebagai salah satu pelayanan emergensi dan elektif di Rumah Sakit (RS) juga harus menyesuaikan kondisi pandemi, karena dapat menjadi area berisiko tinggi transmisi infeksi saluran pernapasan serta dapat mempercepat dan memperparah progresivitas penyakit.

Tujuan: Penelitian ini bertujuan mengidentifikasi standar dan elemen penilaian Pelayanan Anestesi dan Bedah (PAB) dalam Standard Nasional Akreditasi Rumah Sakit (SNARS) Edisi 1.1 yang memerlukan pengembangan dalam perubahan perilaku pelayanan anestesi dan bedah di RS di masa new normal pasca pandemi.

Metode: Penelitian ini merupakan penelitian kualitatif. Data dikumpulkan melalui in-depth interview pada informan yang ditentukan secara snow-ball sampling. Partisipan berasal dari enam RS di Makassar yang berjumlah 30 orang, terdiri atas dokter spesialis kebidanan dan kandungan, dokter spesialis anestesi, dokter spesialis bedah, dokter umum, perawat kamar operasi, dan perawat/bidan di unit rawat inap. Analisis data dilaksanakan melalui pendekatan latent analysis, peneliti melakukan interpretasi secara ekstensif untuk menemukan makna teks yang mendasarinya. Analisis data dilakukan melalui reduksi data, penyajian data, dan penarikan kesimpulan.
\end{abstract}

Hasil: Terdapat tiga konteks utama yang perlu dibenahi selama masa pandemi dan new normal, yaitu alur pasien dan petugas, penggunaan Alat Pelindung Diri (APD), dan metode skrining untuk pasien. Seluruh responden menyatakan bahwa alur pasien dan petugas masih sama seperti masa sebelum pandemi sehingga harus dipisahkan, penggunaan APD yang standar sudah tepat dan benar namun belum ada evaluasi rutin terkait kepatuhan penggunaan APD, serta masih belum jelas metode skrining pasien yang baku, efisien, dan efektif.

Kesimpulan: Diperlukan perubahan perilaku dalam menerapkan alur pelayanan pasien di kamar operasi, penggunaan APD yang sesuai standar. Diperlukan penetapan metode skrining pasien yang jelas demi melindungi tenaga kesehatan dan lingkungan RS. Diperlukan sosialisasi secara intensif dan berkelanjutan kepada para pasien tentang pentingnya dan asas manfaat dari standar operasional prosedur yang diterapkan pada masa pandemi dan new normal.

Kata kunci: Pelayanan bedah dan anestesi, kamar operasi, standar, pandemi, new normal

\section{Latar Belakang}

Pelayanan Kesehatan moderen sedang menghadapi situasi yang mencekam, yaitu Severe Acute Respiratory Syndrome Coronavirus 2 (SARS-CoV-2). Prediksi adanya new normal dalam dunia kesehatan merupakan sebuah tantangan yang tidak dapat dihindarkan ${ }^{1}$. New normal didefinisikan sebagai keadaan dimana sistem dan asumsi baru akan menggantikan sebagian lainnya yang sudah biasa dilakukan dalam segala aspek $^{2}$, termasuk sektor kesehatan.

Pelajaran dari wabah severe acute respiratory syndrome $(S A R S) 2003$ di Ontario, Kanada menunjukkan bahwa petugas kesehatan merupakan penyumbang 51,00\% kasus. Keterlibatan erat ahli anestesi dalam intubasi trakea mempunyai risiko tertular infeksi SARS 13 kali lebih tinggi dibandingkan dengan petugas lainnya. Sehingga secara khusus, pencegahan penularan penyakit kepada pasien dan melindungi petugas layanan kesehatan merupakan prioritas utama pelayanan, terlebih dalam keadaan wabah. Namun, dokter anestesi tidak secara langsung menganggap diri mereka berada di garis depan pencegahan infeksi ${ }^{3}$. Penularan infeksi bakteri dan virus ke pasien ataupun sesama petugas dapat terjadi dari praktik pencegahan dan pengendalian infeksi yang tidak tepat pada prosedur anestesi4.

Lingkungan yang aman bagi pasien juga menjadi lingkungan yang aman bagi para pekerja dan sebaliknya, karena keduanya terkait dengan permasalahan budaya dan sistem yang mendasarinya. Ketidaktepatan pengendalian infeksi, keletihan, atau peralatan yang salah dapat mengakibatkan cedera atau penyakit, tidak hanya bagi petugas, tetapi juga bagi pasien dan 
orang lain dalam institusi. Sehingga budaya keselamatan yang kuat merupakan bagian penting dalam pencegahan kesalahan tersebut. Oleh karena itu, upaya untuk menurunkan tingkat kesalahan medis harus didukung agar dapat mencegah cedera dan penyakit terkait pekerjaan 5 .

Pembedahan sebagai salah satu tindakan emergensi dan elektif di rumah sakit juga harus diperhatikan. Kamar operasi dapat menjadi area berisiko tinggi transmisi infeksi saluran pernapasan. Selain itu, pasien asymptomatic carrier yang akan dilakukan pembedahan dapat berpotensi menularkan virus selama masa inkubasi. Pembedahan mungkin dapat mempercepat dan memperparah progresivitas penyakit ini. Pembedahan tidak hanya menyebabkan gangguan sistem imun, tetapi juga menginduksi respon awal sistem inflamasi ${ }^{6}$.

Pedoman pelayanan anestesi dalam masa pandemi di Indonesia dikeluarkan oleh Perhimpunan Dokter Spesialis Anestesi dan Terapi Intensif Indonesia (PERDATIN)7. Sejalan dengan hal tersebut, Anesthesia Patient Safety Foundation (APSF) memberikan rekomendasi untuk praktik standar di lingkungan kerja anestesi meliputi peningkatan standar praktik selama manajemen jalan napas untuk semua pasien agar mengurangi paparan terhadap sekresi ${ }^{8}$. Persatuan Dokter Spesialis Bedah Umum Indonesia (PABI) juga telah mengeluarkan pedoman kerja bagi seluruh anggota PABI di Indonesia dalam melaksanakan pelayanan bedah, meliputi pembatasan kunjungan ke poliklinik bedah, ataupun beberapa tindakan lain. Namun, untuk kasus kegawatdaruratan bedah tetap dilayani di instalasi gawat darurat ${ }^{6}$.

Oleh karena itu, dalam masa pandemi, ahli anestesi diharuskan untuk meningkatkan tindakan pencegahan dan menyesuaikan praktik anestesi untuk setiap pasien. Secara khusus, dengan meminimalkan jumlah prosedur penghasil aerosol yang dilakukan selama anestesi umum, ahli anestesi dapat mengurangi pajanan terhadap sekresi pernapasan pasien dan risiko penularan virus perioperatif ke petugas kesehatan dan pasien lain 9 . Sehingga perubahan perilaku dan budaya kerja petugas dalam lingkup standar dan elemen penilaian akreditasi rumah sakit merupakan sebuah keharusan yang tidak dapat diingkari, dalam hal ini yaitu standar PAB.

\section{Metode}

Penelitian ini merupakan penelitian kualitatif. Peneliti melakukan proses analisis berupa penentuan standar pelayanan anestesi di masa new normal pasca pandemi. Penelitian kualitatif bersifat sangat komunikatif karena dapat secara detail memberikan informasi melalui penjelasan atau gambaran tentang ruang lingkup yang diteliti. Penelitian ini berusaha mendeskripsikan data, fakta, dan keadaan atau kecenderungan yang ada untuk dianalisis guna memecahkan masalah, atau untuk mencapai keinginan di masa akan datang ${ }^{10}$.

Populasi penelitian merupakan dokter anestesi, dokter bedah, dokter spesialis kebidanan dan kandungan, perawat kamar operasi, maupun bidan yang berasal dari enam RS di Kota Makassar. Penelitian ini menggunakan snow-ball sampling, dimana setelah diperoleh informasi, responden pertama diminta menyebutkan nama kolega atau teman sejawatnya yang dapat memberikan informasi terkait subjek penelitian, sehingga diperoleh informasi yang dapat menambah dan melengkapi informasi dari informan sebelumnya. Penelitian akhirnya melibatkan masing-masing enam dokter spesialis kebidanan dan kandungan (OB 1-6), dokter spesialis anestesi (AN 1-6), dokter umum (UM 1-6), perawat kamar operasi (PKO 1-6), dan perawat/bidan di unit rawat inap (PB 1-6). Seluruh responden berasal dari enam rumah sakit di Makassar.

Instrumen pengumpulan data yang digunakan dalam penelitian ini adalah in-depth interview untuk mendapatkan informasiinformasi terkait perilaku, budaya, maupun standar pelayanan anestesi selama masa pandemi yang harus dipertahankan di masa new normal. Validasi terhadap peneliti sebagai instrumen telah dilakukan, meliputi pemahaman metode penelitian kualitatif, penguasaan wawasan terkait perilaku, budaya, maupun standar pelayanan anestesi, kesiapan peneliti untuk memasuki obyek penelitian, baik secara akademik mauapun logistiknya. Peneliti juga dibantu dengan panduan wawancara dan alat perekam suara.

Analisis data dilakukan dengan cara mengorganisasi data ke dalam kategori, menjabarkan ke dalam unit-unit, melakukan sintesis, menyusun ke dalam pola, memilih mana yang penting dan yang akan dipelajari, dan membuat kesimpulan sehingga mudah dipahami. Analisis data kualitatif dilakukan sejak sebelum memasuki lapangan, selama dan setelah selesai di lapangan ${ }^{11}$.

Data selanjutnya dieduksi, yaitu merangkum, memilih hal-hal yang pokok, memfokuskan pada hal-hal yang penting, diidentifikasi tema dan polanya guna mempermudah pengumpulan data selanjutnya dan mencarinya bila diperlukan ${ }^{12}$. Data yang telah direduksi ditampilkan dalam matriks penelitian berdasarkan kategori untuk memahami kondisi dan fenomena yang terjadi. Data selanjutnya disimpulkan oleh tim peneliti untuk menemukan rekomendasi bagi pelayanan anestesi dan bedah di masa new normal.

Penelitian ini telah mendapatkan ijin dari direktur masingmasing rumah sakit, berdasarkan rekomendasi dari Komite Etik Penelitian (KEP) setiap RS.

\section{Hasil}

Perubahan perilaku pelayanan sebelum dan sesudah pandemi Corona Virus Disease 2019 (Covid-19)

Berdasarkan hasil wawancara, sebagian besar responden menyatakan telah terjadi perubahan perilaku pelayanan sebelum dan sesudah masa pandemi. Seperti yang disampaikan oleh partisipan, "Secara umum semua perilaku berubah, baik pasien maupun para petugas di masa pandemi Covid-19 bila dibandingkan dengan masa sebelumnya, pasien yang ingin dioperasi." (OB1)

Pendapat yang sama juga disampaikan oleh partisipan lain, "Setelah dibandingkan antara masa sebelum corona dengan masa corona sekarang ini, terjadi perubahan sikap pasien, dokter dan perawat operasi." (AN1)

Perilaku pelayanan yang saat ini sudah berubah dari masa sebelum pandemi adalah perubahan sikap dan perilaku terutama pada aspek prosedur dan alat pelindung diri (APD) di berbagai level.

"Sebelum masa pandemi Covid-19, para perawat memakai APD level satu dalam melayani pasien, untuk pasien yang memiliki penyakit khusus, maka para perawat memakai APD level dua. Sedangkan pada masa pandemi ini maka semua pasien yang mau dioperasi, menggunakan APD level tiga yang memiliki standar." (PB2)

Selama masa pandemi dan new normal, semua petugas kamar operasi, medis dan non medis dan seluruh pelayanan 
pembedahan menggunakan APD level tiga dan baju hazmat karena sangat rentan tertular oleh pasien, seperti pernyataan berikut:

"Perlu dipahami bahwa di kamar operasi masa pandemi dan new normal sekarang ini, semua dokter dan petugas para medis dan non medis memakai APD level tiga pakai baju hazmat." (UM3)

Perubahan perilaku pelayanan di setiap rumah sakit selama masa pandemi dibandingkan dengan masa sebelum pandemi adalah juga dalam menekankan agar pasien menjalani rapid test, dan berbagai prosedur pemeriksaan yang sudah ditetapkan rumah sakit, sesuai jenis dan klasifikasi berat ringannya penyakit yang diderita pasien. Partisipan menyatakan bahwa:

\begin{abstract}
"Sebelum pasien memasuki ruang operasi terlebih dahulu dilakukan rapid test sebagai syarat utama pada masa pandemi ini, setelah diperiksa dokumen lainnya termasuk riwayat penyakitnya kemudian setelah dinyatakan negatif, maka barulah pasien tersebut masuk ruang operasi." (OB 6)

"Untuk pasien yang akan dioperasi wajib melalui rapid test, begitu pula prosedur yang harus dilewati pasien pada saat masuk ruang operasi, mulai saat konsultasi riwayat penyakit, hasil laboratorium sampai pada saat pasien memenuhi persyaratan memasuki kamar operasi." (PKO4)
\end{abstract}

Selain itu, terdapat pula prosedur foto rontgen toraks sebelum operasi: "Semua pasien baru harus di rapid test, swab test dan foto toraks sebelum dilakukan operasi sehingga ada jaminan." (UM3)

Partisipan menekankan bahwa harus ada perlakuan yang berbeda antara masa sebelum dengan sesudah pandemic, seperti pernyataan berikut ini:

"Untuk pasien harus ada perlakuan yang berbeda antara masa sebelum covid dengan masa pandemi sekarang ini, terutama adanya jaminan bahwa pasien tersebut, bebas dari covid karena ancaman yang paling dominan adalah terpapar nya para petugas kamar operasi yang diakibatkan oleh status pasien, jika pasien benar reaktif hasil rapid test, maka dianjurkan agar pasien diisolasi selama 14 hari lalu dilakukan tes swab berikutnya. Jika hasil swab kedua dinyatakan negatif maka kegiatan operasi pasien dilanjutkan." (UM1)

Di satu sisi, rapid test berlaku bagi semua pasien yang akan menjalani operasi, sehingga status Orang Dalam Pemantauan (ODP) dan Pasien Dalam Pemantauan (PDP) mudah dipantau dan di deteksi.

Di sisi lain, disimpulkan semua pasien dianggap Orang Tanpa Gejala (OTG) sehingga semua petugas baik dokter, perawat menggunakan APD level tiga, sedangkan pada semua pasien diharapkan agar dilakukan rapid test, Numerical Rating Scale (NRS), dan swab test dengan tujuan untuk mengetahui reaktif atau tidak, sehingga diperlukan tindak lanjut. Berikut ini pertanyaan partisipan:

“.... dan [1] karena semua pasien dianggap OTG maka dokter, perawat kamar operasi menggunakan APD level tiga, serta [2] semua pasien diharapkan semua harus di rapid test, NRS, dan swab test dengan tujuan untuk mengetahui reaktif atau tidak, untuk diambil tindakan lebih lanjut." (AN2)

Hasil temuan di lapangan adalah para petugas dan pasien untuk jalur keluar masuk masih menggunakan satu jalur, sementara seharusnya sudah dipisahkan antara jalur yang dilewati para pasien dengan para petugas operasi, sehingga terbebas dari penyebaran Covid-19 tersebut.

Oleh karenanya, diperlukan perubahan SOP perihal alur pasien dan petugas yang diberlakukan pada masa sebelum dan masa pandemi Covid-19, terutama pada jalur atau pintu masuk dan keluar pasien dipisahkan dengan pintu masuk dan keluar para dokter dan perawat kamar operasi. Dengan demikian terdapat batasan yang bersinggungan secara langsung antara pasien dengan petugas kamar operasi.

Namun demikian, keterbatasan sarana prasarana rumah sakit tentang jumlah dan luasnya ruang tunggu bagi pasien, dan belum adanya pemisahan jalur masuk dan keluar pasien dengan para dokter dan perawat di kamar operasi, dikhawatirkan masih menimbulkan terjadinya kontak dan sentuhan langsung antara petugas kamar operasi dengan pasien dan pengantar pasien. Hal ini disampaikan oleh partisipan berikut ini: "Meskipun diakui bahwa sarana ruang tunggu yang masih perlu ditambah dan jalur yang dilewati pasien harus berbeda dengan jalur yang dilewati dokter dan perawat pada saat masuk ruang operasi." (AN3)

Oleh karena itu, setiap rumah sakit perlu memperhatikan fasilitas ruangan, jalur keluar masuk pasien yang terpisah dengan jalur keluar masuk para petugas.

\section{Saran dan pertimbangan masa new normal}

Sebagian besar responden menyatakan diperlukan skrining bagi pasien yang akan menjalani operasi. Hal ini disampaikan oleh partisipan berikut ini:

$$
\begin{aligned}
& \text { “... Pasien yang ingin dioperasi .... harus di skrining.” (OB1) } \\
& \text { “... Sedangkan pasien harus melalui rangkaian tes Covid-19.” } \\
& \text { (UM1) }
\end{aligned}
$$

"Terutama tambahan syarat pasien pada saat mau dioperasi yaitu rapid test dan riwayat penyakit yang dimiliki pasien." (AN5)

“... Sehingga pihak rumah sakit untuk melengkapi alat tes Covid19 tersebut sebanyak mungkin.” (UM6)

Saran lain muncul selama wawancara adalah ketersediaan sarana dan APD yang memadai dan memenuhi standar bagi para dokter dan perawa. Hampir seluruh responden menyarankan bahwa ketersediaan APD merupakan hal yang sangat penting bagi petugas di kamar operasi. Seperti yang disampaikan oleh partisipan berikut ini:

"Sehingga disarankan kepada pihak rumah sakit untuk melengkapi .... dan begitu pula pakaian hasmat untuk bagian operasi yang lengkap lebih dari satu per orang, agar lebih steril dalam penggunaannya." (UM6)

"Semua petugas harus memakai APD level tiga, baik tidak melakukan operasi maupun pada saat melakukan operasi." (AN6)

"Disiapkan pula satu orang petugas dalam memeriksa APD para petugas operasi sebelum masuk ke dalam ruang operasi." (PKO1)

Sedangkan dari sisi ruangan yang ada di rumah sakit harus dipisahkan antara jalur yang dilalui pasien yang akan dioperasi dengan para petugas yang akan memasuki ruang operasi. Setidaknya saran ini diajukan oleh seluruh responden dokter anestesi. Seperti yang disampaikan oleh partisipan berikut ini: "Harus disiapkan jalur masing-masing pasien dan para petugas operasi pada saat memasuki ruang operasi." (AN4)

Penerapan standar operasional baru dalam pelayanan bedah dan anestesi harus disosialisasikan secara berkelanjutan kepada pasien. Hal ini dapat dilihat dari pernyataan partisipan berikut ini: 
"Pada masa pandemi ini, pasien mengalami hal yang baru sebelum dioperasi, bahwa sikap dan pengetahuan tentang Covid-19, masih sebatas pengetahuan dasar dan informasi yang belum mendalam tentang cara menjalankan protokol kesehatan, diperlukan kegiatan ekstra dari para perawat dibagian administrasi dan pemeriksaaan awal untuk menjelaskan secara detail prosedur yang harus dilewati pada masa pandemi ini." $\left(\mathrm{PKO}_{3}\right)$

"Jika dicermati para pasien yang datang masih perlu disosialisasikan secara berkelanjutan tentang Standar Operasional Prosedur [SOP] kamar operasi pada masa Covid-19, agar pasien datang sudah siap dan tidak perlu lagi bingung atau kurang ikhlas untuk melewati berbagai pemeriksaan secara tepat dan cepat." (PB1)

\section{Pembahasan}

Berdasarkan hasil penelitian, maka perlu diuraikan secara rinci perubahan perilaku pelayanan yang ada di rumah sakit selama masa new normal. Pertama adalah perubahan perilaku pasien. Setelah membandingkan kondisi yang dialami para pasien pada masa sebelum pandemi dengan masa pandemi kemudian memasuki masa new normal memerlukan perubahan sikap dan perilaku yang mendorong pasien dapat menerima alur prosedur yang telah ditetapkan rumah sakit pada saat pasien ingin dioperasi, sehingga pasien sadar akan prosedur tersebut demi kebaikan pasien sendiri beserta keluarganya serta orang lain yang pernah berinteraksi.

Perubahan perilaku sebagai akibat adanya rangsangan dan kondisi yang dialami seseorang sehingga ada perubahan perilaku yang dijalaninya ${ }^{13}$. Perubahan perilaku seseorang dipengaruhi oleh predisposisi faktor, sikap, nilai-nilai kepercayaan dan persepsi yang dimilikinya ${ }^{14}$. Pengetahuan dasar yang dimiliki tentang Covid-19, masih perlu diberi stimulus terkait pemahaman secara detail beserta akibat yang ditimbulkan dari Covid-19 tersebut. Masih banyaknya asumsi para pasien bahwa hanya orang-orang tertentu yang dapat terinfeksi Covid-19, terutama yang berusia 50 tahun ke atas, memiliki riwayat penyakit bawaan. Sementara banyak sekali orang yang terinfeksi Covid-19 walaupun OTG, sehingga perlu diwaspadai dan ditempuh langkah-langkah preventif secara prosedur, karena sangat rentan terinfeksi virus Covid-19. Virus ini dapat menyebar pada ruang operasi dan dapat mengakibatkan transmisi antara lingkungan ke petugas kesehatan dan pasien bilamana APD tersebut tidak digunakan sebagaimana standar pemakaiannya.

Adanya beberapa tindakan prosedur yang harus dilewati para pasien yang akan menjalani operasi, antara lain, terdapat hasil rapid test yang dapat menjamin pasien terdeteksi secara dini tentang Covid-19, kemudian diikuti prosedur persyaratan administrasi dari riwayat status pasien baru maupun lama sehingga dapat diagnosis secara dini jenis penyakit dan tingkat penyakitnya.

Pasien harus diedukasi untuk menjalani SOP rumah sakit terkait protokol kesehatan masa pandemi Covid-19, dimulai saat datang, duduk di ruang tunggu, menunggu antrian, melengkapi administrasi yang diminta oleh para petugas loket, prosedur memasuki ruang operasi, hingga selesai dilakukannya operasi pada masa pandemi ini.

Kedua, perubahan perilaku petugas. Petugas ruang operasi terdiri atas dokter dan perawat ruang operasi yang memerlukan perubahan perilaku dalam melakukan operasi pada pasien. Diperlukan pengetahuan dan pemahaman yang benar tentang penggunaan APD bagi para petugas tersebut sesuai standard pemakaian APD yang baik dan benar mulai dari APD level satu maupun pada level tiga. Adanya sikap yang sabar dan telaten serta ulet selama masa penggunaan APD baik pada saat melakukan operasi maupun pada pasca operasi tersebut.

Para petugas operasi dapat mengikuti SOP yang telah diterapkan pihak rumah sakit pada pandemi ini, sehingga dapat meminimalkan risiko hingga memutus mata rantai penyebaran virus Covid-19. Para petugas harus mampu disiplin dalam menegakkan aturan yang harus dilalui oleh pasien selama operasi dan pasca operasi. Begitu pula pada saat memberikan pengertian dan pemahaman kepada pasien dalam menjalankan prosedur tersebut.

Dipertegas pula hasil tinjauan konseptual dari PERDATIN tentang pedoman pelayanan anestesia dalam masa pandemi di Indonesia ${ }^{15}$, didukung pula rekomendasi untuk praktik standard di lingkungan kerja anestesia yang meliputi peningkatan standar praktik selama manajemen jalan napas untuk semua pasien dalam rangka mengurangi paparan terhadap sekresi ${ }^{16}$. Begitu pula rekomendasi dari Persatuan Dokter Spesialis Bedah Umum Indonesia (PABI) tentang pedoman kerja bagi seluruh anggota PABI dalam melaksanakan pelayanan bedah ${ }^{6,17}$, yang diperjelas lagi oleh SNARS 1.1.

Ketiga, penyediaan sarana prasarana. Merujuk pada hasil penelitian, penyediaan sarana prasarana menjadi wajib bagi rumah sakit untuk difasilitasi dalam penyediaannya. Adapun sarana dan prasarana yang dimaksud yaitu APD yang standar dilengkapi dengan petunjuk dan cara penggunaannya, adanya ruang tunggu pasien yang representatif dengan social distance serta adanya jalur khusus pasien menuju ruang operasi yang terpisah dengan para petugas operasi tersebut, sebagai bukti rumah sakit peka dan peduli terhadap tingkat kenyamanan dan keselamatan pasien dan para petugas yang ada. Artinya, pihak rumah sakit harus mampu mengantisipasi kondisi new normal masa pandemi ini dalam memberikan pelayanan kepada pasien khususnya pada ruang operasi, tidak boleh menimbulkan kesan bahwa pihak rumah sakit menyediakan sarana prasarana tersebut sesuai dengan kemampuannya, harus diciptakan kolaborasi dan kemitraan dari para pihak terutama pemerintah dalam penanganan pasien pada masa new normal.

Berdasarkan hasil penelitian, disarankan sebuah skema pelayanan anestesi dan bedah di masa new normal. Kedatangan pasien harus segera dilayani di loket administrasi. Pasien lalu diarahkan untuk menuju pemeriksaan skrining Covid-19 berupa rapid test. Pasien yang terkonfirmasi positif, harus menjalani isolasi sesuai SOP pelayanan pasien dengan Covid-19. Pasien dengan hasil negatif pada pemeriksaan awal, maka dapat diarahkan ke ruang operasi. Sementara petugas harus mempunyai ruangan dan jalur yang terpisah dengan pasien sebelum memasuki ruang operasi.

\section{Kesimpulan}

Telah terjadi perubahan pelayanan anestesi dan bedah selama masa pandemi, terutama dalam hal penggunaan APD dan perlunya skrining pasien yang akan menjalani operasi. Pasien harus dipandu melalui edukasi secara berkelanjutan agar dapat mematuhi standar pelayanan selama masa pandemi.

Diperlukan perubahan perilaku para pasien dalam memahami dan melaksanakan SOP kamar operasi pada masa new normal pandemic, melalui pemeriksaan rapid test, swab test maupun ketentuan lainnya yang telah ditetapkan pihak rumah sakit. Selain itu, sosialisasi secara intensif dan berkelanjutan harus diberikan kepada para pasien tentang pentingnya dan asas 
manfaat SOP yang diterapkan pada masa pandemi new normal. Para petugas juga harus mematuhi aturan dan disiplin dalam penggunaan APD sesuai standar pemakaiannya. Sementara itu, pihak rumah sakit diharapkan dapat menyediakan sarana dan prasarana yang memadai baik fasilitas ruang tunggu, jalur khusus pasien ke kamar operasi, penyediaan APD yang berstandar.

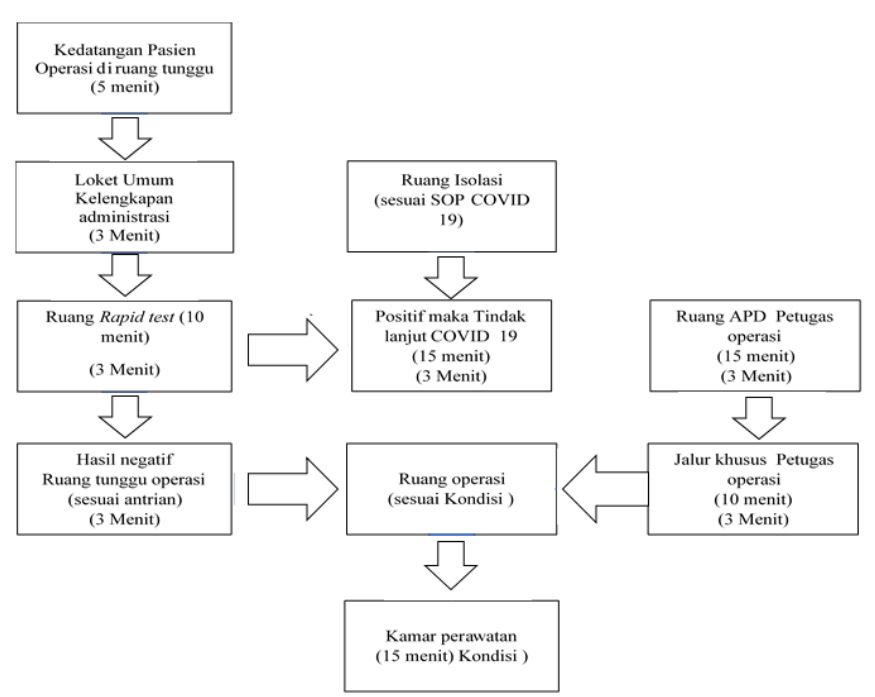

Gambar 1. Rekomendasi alur pelayanan kamar operasi masa new normal

\section{Referensi}

1. Berwick DM. Choices for the "new Normal." JAMA - J Am Med Assoc. 2020; 5:20-1.

2. Candelon B, Carare A, Miao K. Revisiting the new normal hypothesis. J Int Money Financ. 2016;66(2015):5-31.

3. Bowdle A, Munoz-Price LS. Preventing Infection of Patients and Healthcare Workers Should Be the New Normal in the Era of Novel Coronavirus Epidemics. Anesthesiology. 2020 Jun;132(6):1292-5.

4. Dolan SA, Heath J, Potter-Bynoe G, dkk. Infection prevention in anesthesia practice: A tool to assess risk and compliance. Am J Infect Control. 2013;41(11):1077-82.

5. IOM. To Err Is Human: Building a Safer Health System Linda. Kohn LT, Corrigan JM, Donaldson MS, editors. Institute of
Medicine: Committee on Quality of Health Care in America. National Academy Press; 2000.

6. Wetan NGAAMY, Novianti PA. Strategi Pembedahan di Era Pandemi COVID-19. JBN (Jurnal Bedah Nasional). 2020;4(1):11.

7. PERDATIN. Penanganan Pasien Kritis COVID-19. Jakarta: Perhimpunan Dokter Spesialis Anestesi dan Terapi Intensif Indonesia (PERDATIN); 2020.

8. Liana Z, Nadav L, Desire K, dkk. Perioperative Considerations for the 2019 Novel Coronavirus (COVID-19) - Anesthesia Patient Safety Foundation. Novel Coronavirus (COVID-19) Anesthesia Resource Center. 2020.

9. Lie SA, Wong SW, Wong LT, dkk. Practical considerations for performing regional anesthesia: lessons learned from the COVID19 pandemic. Can J Anesth. 2020;

10. Moleong LJ. Metodologi penelitian kualitatif. 38th ed. Bandung: Remaja Rosdakarya; 2018.

11. Miles MB, Huberman AM, Saldaña J. Qualitative data analysis: a methods sourcebook. 3rd ed. SAGE Publications, Inc.; 2014.

12. Sugiyono. Metode Penelitian Kualitatif. Bandung: Alfabeta; 2013.

13. Lourenco F, Casey BJ. Adjusting behavior to changing environmental demands with development. Neurosci Biobehav Rev [Internet]. 2013 Nov;37(9):2233 42. Available from: https:// linkinghub.elsevier.com/retrieve/pii/So149763413000638

14. Lawrence W. Green. Modifying and Developing Health Behavior. Annu Rev Public Health [Internet]. 1984; 5:215. Available from: https://doi.org/10.1146/annurev.pu.05.050184.0 $01243 \%$ oA\%oA

15. Burhan E, Susanto AD, Nasution SA, dkk. PEDOMAN TATALAKSANA COVID-19 Edisi 3 TIM EDITOR Perhimpunan Dokter Paru Indonesia (PDPI) Perhimpunan Dokter Spesialis Kardiovaskular Indonesia (PERKI) Perhimpunan Dokter Spesialis Penyakit Dalam Indonesia (PAPDI) Perhimpunan Dokter Anestesiologi dan Terap. 2020. 3-6, 88-89 p.

16. Zucco L, Levy N, Ketchandji D, dkk. An Update on the Perioperative Considerations for COVID-19 Severe Acute Respiratory Syndrome Coronavirus-2 (SARS-CoV-2). APSF Newsl [Internet]. 2020;35(2):40_1. Available from: https://www.apsf.o $\mathrm{rg} / \mathrm{wp}$-content/uploads/newsletters/2020/3502/APSF350 2.pdf

17. Persatuan Ahli Bedah Umum Indonesia. Panduan Pelayanan Bedah Umum Menghadapi Pandemi Covid-19 di Indonesia. Jakarta: Persatuan Ahli Bedah Umum Indonesia; 2020. 